\title{
Forum Shopping between Luxembourg and Strasbourg?
}

verfassungsblog.de/forum-shopping-zwischen-luxemburg-und-strassburg/

On the 5th and 6th of May the European Court of Justice (ECJ) held a full Court hearing in Luxembourg concerning the agreement on the accession of the European Union (EU) to the European Convention on Human Rights (ECHR). According to Stian Øby Johansen's detailed eye-witnessreport, all 28 EU member states and all three EU institutions involved (Commission, Parliament and Council) pleaded to declare the agreement to be in conformity with the EU Treaties. Naturally, the unanimous pro-accession pleadings did not prevent the ECJ from going through a long list of questions. Reading Johansen's account, the heated discussion about Protocol No 16 to the ECHR catches the eye. Johansen speaks of an "aggressive line of reasoning from the judges" concerning a potential "forum shopping" between Luxembourg and Strasbourg which could endanger the autonomy of the EU legal order. Was Daniel Thym right after all contrary to Marten Breuer's and my opinion?

\section{Protocol No 16 to the ECHR}

The ECHR has been amended multiple times in its history. Arguably the most important change came with Protocol No 11 which created the European Court of Human Rights (ECtHR) as a standing Court in Strasbourg, to which anyone can apply after exhausting local remedies. The last Protocol to the ECHR that entered into force was Protocol No 14 which paved the way for accession of the EU to the ECHR. Simultaneously with the ensuing accession negotiations, the contracting parties of the ECHR elaborated on Protocols No 15 and 16 . The latter shall enable highest national courts and tribunals to ask the ECtHR for advisory opinions. Although modelled after the preliminary reference procedure to the ECJ, the Protocol No 16 advisory opinion is quite distinct from its EU law archetype: it is exclusively open to the highest courts, it is completely voluntary, and the ECtHR's advisory opinion is not binding. Protocol No 16 will enter into force when ten contracting parties of the ECHR have ratified it (at the moment, ten states have signed the Protocol, including the EU member states Estonia, Finland, France, Italy, Netherlands, Slovakia, and Slovenia). Whether Protocol No 16 will help to decrease the ECtHR's workload by diminishing the number of applications or whether the opposite will hold true, is open to debate. In any event, there will be a new option for dialogue between national apex courts and the ECtHR.

Does EU law pose limits to such dialogue? Obviously, there is the preliminary reference procedure which grants the ECJ the last word with regard to the EU legal order. In addition, the ECJ's case law on the autonomy of the EU legal order could imply that the highest national courts of the EU member states are precluded from asking for advisory opinions in matters of EU law altogether, thus securing the ECJ's position as the sole interlocutor of national courts in EU law matters.

\section{Primacy of the preliminary reference procedure}

EU law (Article 267(3) TFEU) prohibits "forum shopping" between Luxembourg and Strasbourg, as it requires national courts of last resort to initiate a preliminary reference procedure to the ECJ if EU law is relevant to deciding the case. Such courts cannot validly discharge that obligation by asking for an advisory opinion of the ECtHR. What if a lower court has already asked for a decision by the ECJ? In this scenario, there is no obligation for the national court of last resort to ask for a preliminary reference decision once again according to the CILFIT-case law. Nevertheless, the ECJ's judgment on the matter remains binding throughout the entire national procedure up to the court of last resort - at least as long as it has not been overturned by a divergent judgment of the ECJ following a second preliminary reference in the same case. Such new preliminary reference should be admissible if the ECtHR in the meantime has interpreted the corresponding ECHR-right in a different manner. In any event, the national courts of last resort must respect not only their obligations under CILFIT but also under Foto-Frost, to which Tobias Lock was right to point. Hence, should it follow incidentally from an advisory opinion of the ECtHR that an act of EU secondary law is incompatible with the ECHR, the national court of last resort would be obliged to make a preliminary reference on the act's validity if it shares the ECtHR's concerns. Thus the ECJ would have the last word. It would be for Luxembourg to decide either to stick to its previous judgment or to follow Strasbourg. 


\section{No advisory opinions of the ECtHR in cases that involve EU law?}

On the basis of the rationale underlying the ECJ's case law on the autonomy of the EU legal order, the highest courts of the EU member states could be precluded altogether from asking for advisory opinions under Protocol No 16, if EU fundamental rights are applicable in the case at hand. Extrapolating from what it held in Opinion 1/91 (EEA agreement) and 1/09 (unified patent litigation system), the ECJ could find that the EU's judicial system as "a complete system of legal remedies and procedures" does not allow for an intermediate decision (even if not binding) by an external court whose interpretation of international law is relevant for the corresponding EU law. A decision is intermediate in this sense if it precedes the final decision of the national court applying EU law (as the case may be based on a preliminary reference decision by the ECJ). An advisory opinion under Protocol No 16 in a case where EU fundamental rights are applicable would be as such a forbidden intermediate decision. Thus the ECtHR would be limited to an ex post control. The prohibition for highest national courts to ask for advisory opinions under Protocol No 16 resembles Article 344 TFEU which prohibits inter-state applications under Article 33 ECHR by EU member states in matters of EU law. According to the ECJ's ruling in Moxplant, Article 344 TFEU must be understood as a specific expression of the member states' general duty of loyalty which now is enshrined in Article 4(3) TEU. The ECJ ruled that Ireland had violated this duty by launching dispute-settlement proceedings under the United Nations Convention on the Law of the Sea (UNCLOS). With a view to advisory opinions under Protocol No 16, the ECJ could come to the same verdict.

\section{The accession agreement remains unaffected}

Irrespective of the precise limits which EU law poses to the dialogue between highest national courts and the ECtHR, the conformity of the accession agreement with the EU Treaties remains unaffected by that issue. There is an important difference between inter-state applications or advisory opinions under Protocol No 16 on the one hand and individual applications on the other. The individual may bring any case to Strasbourg, including cases that involve EU law, and no one can stop him/her from doing so. For these cases the accession agreement provides for a "co-respondent mechanism" which also ensures that the ECJ gets involved (if it has not had the chance to rule on the matter). In case of inter-state applications or advisory opinions, the EU member states themselves or their highest courts would bring a case that involves EU law to Strasbourg. To prevent such a scenario, it is sufficient to prohibit such course of action under EU law which is binding on the EU member states and on each of their institutions, including courts. This obligation under EU law can be enforced by instruments under EU law, notably infringement procedures. Thus the accession agreement does not need to regulate what is already forbidden under EU law.

\section{Conclusion}

The ECJ itself may prevent highest national courts from "forum shopping" by calling for attention to their obligations under EU law. In any event, Protocol No 16 is no suitable scapegoat to stop the EU from acceding to the ECHR, contrary to what some observers suspected, according to Stian Øby Johansen. The ECJ may stress the limits for judicial dialogue between highest national courts and the ECtHR, but Strasbourg must be able to exercise an ex post control as this is the main purpose of the mandatory accession of the EU to the ECHR and has nothing to do with "forum shopping".

\section{LICENSED UNDER CC BY NC ND}

SUGGESTED CITATION Streinz, Thomas: Forum Shopping between Luxembourg and Strasbourg?, VerfBlog, 2014/6/17, http://verfassungsblog.de/forum-shopping-zwischen-luxemburg-und-strassburg/.

Anfang Mai verhandelte der Europäische Gerichtshof (EuGH) auf dem Luxemburger Kirchberg in voller Besetzung über das Abkommen zum Beitritt der Europäischen Union (EU) zur Europäischen Menschenrechtskonvention (EMRK). Dem lesenswerten Augenzeugenbericht Stian Øby Johansens zufolge plädierten alle 28 EU-Mitgliedstaaten und die drei beteiligten EU-Institutionen Kommission, Parlament und Rat dafür, das Beitrittsabkommen für unionsrechtskonform zu erklären. Die beitrittskritische Rolle fiel so dem Gerichtshof zu, der mit den Verfahrensbeteiligten einen Fragenkatalog abarbeitete. Hierbei sticht vor allem die Diskussion über die Auswirkungen von Protokoll Nr. 16 zur EMRK ins Auge. Stian Øby Johansen berichtet von „aggressiven Fragen der Richter" hinsichtlich eines möglichen "forum shopping” zwischen Luxemburg und 
Straßburg, das die Autonomie der Unionsrechtsordnung gefährden könne. Sollte Daniel Thym entgegen anderen Stimmen doch Recht behalten?

\section{Protokoll Nr. 16 zur EMRK}

Die EMRK hat im Laufe ihrer Geschichte zahlreiche Ergänzungen erfahren. Die wohl wichtigste Änderung war Protokoll Nr. 11, das den Europäischen Gerichtshof für Menschenrechte (EGMR) als ständigen Gerichtshof in Straßburg errichtete, an den sich jedermann nach Erschöpfung des nationalen Rechtswegs wenden kann. Zuletzt machte Protokoll Nr. 14 den Weg frei für den Beitritt der EU zur EMRK. Zeitgleich zu den Beitrittsverhandlungen erarbeiteten die EMRK-Vertragsparteien Protokoll Nr. 15 und 16. Letzteres soll nationalen Höchstgerichten die Möglichkeit eröffnen, Gutachtenanfragen an den EGMR zu richten. Obwohl dem Vorabentscheidungsverfahren zum EuGH nachgebildet, unterscheidet sich das Verfahren nach Protokoll Nr. 16 in wesentlichen Punkten: Es steht ausschließlich Höchstgerichten offen, ist stets freiwillig und das Gutachten des EGMR ist nicht bindend. Das Protokoll tritt in Kraft, sobald es zehn EMRK-Vertragsparteien ratifiziert haben (derzeit haben es elf Staaten unterzeichnet, darunter die EU-Mitgliedstaaten Estland, Finnland, Frankreich, Italien, Litauen, Niederlande, Slowakei und Slowenien). Ob das EGMR-Gutachtenverfahren zur Entlastung beiträgt, weil sich Individualbeschwerden erübrigen, oder sich diese Hoffnung in ihr Gegenteil verkehrt, wird die Zukunft zeigen. Jedenfalls eröffnet es eine neue Dialogoption zwischen den nationalen Höchstgerichten und dem EGMR.

Setzt das Unionsrecht diesem Dialog Grenzen? Unstreitig ist der Vorrang des Vorabentscheidungsverfahrens, das dem EuGH mit Blick auf die Unionsrechtsordnung das letzte Wort garantiert. Die Rechtsprechung des EuGH zur Autonomie des Unionsrechts lässt sich aber auch dahingehend verstehen, dass mitgliedstaatlichen Höchstgerichten Gutachtenanfragen nach Protokoll Nr. 16 in unionsrechtlichen Sachverhalten gänzlich untersagt sind, um sicherzustellen, dass der EuGH der einzige Ansprechpartner für mitgliedstaatliche Gerichte in Unionsrechtsfragen bleibt.

\section{Vorrang des Vorabentscheidungsverfahrens}

Das Unionsrecht (Art. 267 Abs. 3 AEUV ) steht einem „forum shopping“ zwischen Straßburg und Luxemburg entgegen, indem es letztinstanzliche Gerichte zur Einleitung eines Vorabentscheidungsverfahrens zum EuGH zwingt, wenn unionsrechtliche Fragen entscheidungserheblich sind. Dieser Verpflichtung können sich die mitgliedstaatlichen Höchstgerichte nicht durch eine Gutachtenanfrage an den EGMR nach Protokoll Nr. 16 entziehen. Was aber, wenn bereits ein Instanzgericht von seinem Vorlagerecht Gebrauch gemacht hat? Dann entfällt zwar für das nationale Höchstgericht nach der CILFIT-Rechtsprechung die Vorlagepflicht. Aber das Urteil des EuGH entfaltet durch den gesamten nationalen Instanzenzug bis zum Höchstgericht eine ,innerprozessuale Bindungswirkung", die nur durch ein auf eine erneute Vorlage ergangenes abweichendes Urteil des EuGH überwunden werden kann. Eine solche erneute Vorlage im laufenden Instanzenzug dürfte zulässig sein, wenn der EGMR zwischenzeitlich das mit einem EU-Grundrecht korrespondierende EMRK-Grundrecht abweichend vom EuGH ausgelegt hat. Außerdem müssen nationale Gerichte nicht nur CILFIT, sondern auch Foto-Frost beachten, worauf Tobias Lock zu Recht hingewiesen hat: Ergibt sich aus einem EGMR-Gutachten inzident die EMRK-Widrigkeit eines Sekundärrechtsakts, so darf das nationale Höchstgericht diesen nicht schon aus diesem Grund unangewendet lassen. Vielmehr müsste es zwingend eine Gültigkeitsvorlage an den EuGH richten, wenn es die Bedenken des EGMR teilt. Der EuGH hätte folglich in jedem Fall das letzte Wort und müsste selbst entscheiden, ob er sein vorheriges Urteil revidiert und dem EGMR folgt oder nicht.

\section{Verbot von Gutachtenanfragen an den EGMR in unionsrechtlichen Sachverhalten?}

\section{Darüber hinaus könnte der EuGH in Fortführung seiner Rechtsprechung zur Autonomie der}

Unionsrechtsordnung feststellen, dass mitgliedstaatlichen Höchstgerichten Gutachtenanfragen nach Protokoll Nr. 16 gänzlich untersagt sind, wenn die Auslegung von (mit der EMRK korrespondierenden) EU-Grundrechten für das Ausgangsverfahren entscheidungserheblich ist. Aus den vom EuGH in den Gutachten 1/91 (EWRAbkommen) und 1/09 (EU-Patentgerichtsbarkeit) entwickelten Maßstäben ließe sich insofern ableiten, dass dem Gerichtssystem der Union als „vollständigem System von Rechtsbehelfen und Verfahren“ jede Zwischenentscheidung (sogar eine nicht bindende) eines externen Gerichts fremd ist, dessen Auslegung des 
Völkerrechts sich auf (inhaltsgleiches) Unionsrecht auswirkt. Eine solche Zwischenentscheidung läge immer dann vor, wenn sie vor der abschließenden Entscheidung ergeht, in der ein nationales Gericht (ggf. nach Vorlage an den EuGH) das Unionsrecht anwendet. Eine Gutachtenanfrage nach Protokoll Nr. 16 in einem Verfahren, in dem EU-Grundrechte entscheidungserheblich sind, wäre daher eine verbotene Zwischenentscheidung. Die Kontrolle durch den EGMR dürfte nur nachträglich erfolgen, die nationalen Höchstgerichte dürften den EGMR ergo nicht schon zwischenzeitlich mittels einer Gutachtenanfrage einschalten. Ein derartiges Verbot erinnert an die Verpflichtung aus Art. 344 AEUV, demzufolge die EUMitgliedstaaten bei unionsrechtlichen Streitfragen von der Staatenbeschwerde nach Art. 33 EMRK keinen Gebrauch machen dürfen. In der Lesart des EuGH in der Moxplant-Entscheidung handelt es sich bei Art. 344 AEUV um eine Ausprägung des Grundsatzes der Unionstreue. Der EuGH entschied, dass Irland gegen diesen Grundsatz verstieß, indem es ein Streitschlichtungsverfahren nach dem Seerechtsübereinkommen einleitete. Im Hinblick auf Gutachtenanfragen nach Protokoll Nr. 16 könnte der EuGH zum selben Ergebnis gelangen.

\section{Keine Auswirkungen auf das Beitrittsabkommen der EU zur EMRK}

Unabhängig davon, welche Grenzen das Unionsrecht dem Dialog zwischen mitgliedstaatlichen Höchstgerichten und dem EGMR zieht: Die Primärrechtskonformität des Beitrittsabkommens bleibt von der Problematik des Protokolls Nr. 16 unberührt. Denn das Beitrittsabkommen muss nicht völkerrechtlich regeln, was schon unionsrechtlich verboten ist. Die Konstellationen der Staatenbeschwerde oder des EGMR-Gutachtenverfahrens unterscheiden sich insofern grundlegend von derjenigen der Individualbeschwerde, durch die der Einzelne (auch) unionsrechtliche Sachverhalte nach Straßburg bringen kann, ohne dass inn jemand daran hindern könnte. Für diese Fälle gibt es den Mit-Beschwerdegegnermechanismus („co-respondent mechanism“), der auch sicherstellt, dass der EuGH beteiligt wird (sofern noch nicht geschehen). Im Wege der Staatenbeschwerde oder des EGMR-Gutachtenverfahrens würden dagegen die EU-Mitgliedstaaten selbst bzw. ihre Gerichte unionsrechtliche Sachverhalte nach Straßburg tragen. Um dies zu unterbinden, ist ein unionsrechtliche Verbot vollkommen ausreichend, da die EU-Mitgliedstaaten und jedes ihrer Organe (einschließlich der Gerichte) zur Beachtung des Unionsrechts verpflichtet sind. Diese unionsrechtliche Verpflichtung lässt sich auch mit unionsrechtlichen Mitteln, d.h. dem Vertragsverletzungsverfahren durchsetzen.

\section{Fazit}

Der EuGH kann einem „forum shopping“ selbst Einhalt gebieten, indem er den mitgliedstaatlichen Gerichten ihre unionsrechtlichen Pflichten in Erinnerung ruft. Protokoll Nr. 16 taugt daher auch nicht - wie laut Stian Øby Johansen von einigen Prozessbeobachtern vermutet - als Vorwand, um den Beitritt der EU zur EMRK zu verhindern. Luxemburg mag dem Dialog der mitgliedstaatlichen Höchstgerichte mit Straßburg unionsrechtliche Schranken setzen. Dies ändert aber nichts daran, dass die EuGH-Rechtsprechung jedenfalls nachträglich der externen Kontrolle Straßburgs unterworfen wird, denn das ist gerade Sinn und Zweck des - nach Art. 6 Abs. 2 EUV verpflichtenden - Beitritts der EU zur EMRK und hat mit „forum shopping“ nichts zu tun.

\section{LICENSED UNDER CC BY NC ND}

SUGGESTED CITATION Streinz, Thomas: Forum Shopping zwischen Luxemburg und Straßburg?, VerfBlog, 2014/6/17, http://verfassungsblog.de/forum-shopping-zwischen-luxemburg-und-strassburg/. 